\title{
KONSEP TRANSITIONAL JUSTICE DALAM PENANGANAN PELANGGARAN HAM BERAT DI INDONESIA
}

\author{
Asher Tumbo \\ Universitas Kristen Indonesia Paulus; ashertumbo@ukipaulus.ac.id
}

\begin{abstract}
Abstrak
Kekuasaan negara yang otoriter selalu membawa dampak pada pelanggaran terhadap Hak Asasi Manusia. Bahkan, dalam masa pergantian kekuasaan yang otoriter dalam suatu negara menuju pemerintahan yang demokratis seringkali meninggalkan luka berupa pelanggaran berat terhadap Hak Asasi Manusia. Kondisi ini diperparah dengan ketidakmampuan lembaga peradilan untuk memberikan rasa keadilan bagi para korban pelanggaran berat Hak Asasi Manusia yang dilakukan oleh pemerintah yang berkuasa. Indonesia juga pernah mengalami hal serupa, di mana terjadi pelanggaran berat Hak Asasi Manusia dilakukan oleh pemerintah yang otoriter. Sekian peristiwa pelanggaran berat Hak Asasi Manusia bahkan tidak dapat terselesaikan hingga saat ini. Konsep Transitional Justice dinilai menjadi salah satu jawaban atas persoalan pelanggaran berat Hak Asasi Manusia yang pernah terjadi di Indonesia. Penulisan artikel ini akan menganalisis konsep Transitional Justice dalam penanganan pelanggaran berat Hak Asasi Manusia di Indonesia. Tujuan dari penulisan ini adalah untuk mengetahui penerapan konsep Transitional Justice di Indonesia. Berdasarkan analisis yang digunakan, ditemukan bahwa penerapan konsep Transitional Justice di Indonesia bisa dilakukan jika terdapat lembaga yang bernama Komisi Kebenaran dan Rekonsiliasi.
\end{abstract}

Kata Kunci : Transitional Justice; Pelanggaran HAM

\begin{abstract}
Authoritarian state power always has an impact on violations of human rights. In fact, in a period of authoritarian change of power in a country towards democratic governance often leaves scars in the form of gross violations of human rights. This condition is exacerbated by the inability of the judiciary to provide a sense of justice for victims of gross human rights violations committed by the ruling government. Indonesia has also experienced the same thing, where gross violations of human rights were committed by an authoritarian government. Some of the gross violations of human rights have not even been resolved to date. The concept of Transitional Justice is considered to be one of the answers to the problem of gross human rights violations that have occurred in Indonesia. This article will analyze the concept of Transitional Justice in dealing with gross human rights violations in Indonesia.The purpose of this paper is to find out the application of the concept of Transitional Justice in Indonesia.Based on the analysis used, it was found that the application of the concept of Transitional Justice in Indonesia could be done if there was an institution called the Truth and Reconciliation Commission.
\end{abstract}

Keywords : Transitional Justice; Human Rights Violations

\section{Pendahuluan}

Hak Asasi Manusia adalah seperangkat hak yang melekat pada hakikat dan keberadaan manusia sebagai mahkluk Tuhan Yang Maha Esa dan merupakan 
anugerah-Nya yang wajib dihormati, dijunjung tinggi dan dilindungi oleh negara, hukum dan pemerintah, dan setiap orang demi kehormatan serta harkat dan martabat manusia. ${ }^{1}$ Urgensinya penghormatan terhadap hak asasi karena diberikan oleh Tuhan secara lansung sejak lahir sehingga tak bisa dikurangi oleh siapapun bahkan negara. Gagasan atau ide tentang HAM, muncul setelah berakhirnya Perang Dunia II bahwa hak asasi tersebut harus dilindungi oleh hukum. Maka dari itu, Perserikatan Bangsa Bangsa (PBB) sebagai lembaga dunia kemudian membahas mengenai gagasan HAM yang terdiri atas aspek universal, kepatutan-kepatutan dan kemerdekaan yang harus tetap ditegakan tanpa membedakan ras, warna kulit, jenis kelamin, bahasa, agama, politik maupun pendapat lain yang berlainan mengenai asal mula kebangsaan atau kemasyarakatan, hak milik, kelahiran ataupun kedudukan lainnya. Fakor-faktor inilah yang melatarbelakangi The Universal Declaration Of human Rights pada tanggal 10 Desember 1948, yang didukung oleh 160 Negara. Penghormatan terhadap HAM sangat penting karena hak yang terkandung dalam diri manusia merupakan pemberian Tuhan oleh karenanya harus dihormati dan dilindungi.

Secara umum, Keadilan Transisional (Transitional Justice), dipahami sangat terkait dengan pelanggaran hak asasi manusia (HAM) yang secara sistematis terjadi di masa lalu dalam proses demokratisasi yang diselesaikan melalui prosedur yudisial seperti lewat pengadilan di dalam negeri atau pengadilan internasional, maupun prosedur non-yudisial lewat Komisi Kebenaran dan Rekonsiliasi (KKR). Menurut "The Rule of Law and Transitional Justice in Conflict and Post-conflict Societies", berupa laporan Sekjen PBB yang diajukan kepada Dewan Keamanan PBB, keadilan transisi didefenisikan untuk memastikan pihak yang harus bertanggungjawab atas pelanggaran HAM berat, meluas dan sistematis di masa lalu, sebagai upaya mewujudkan keadilan dan mencapai perdamaian, maka segala proses dan mekanismenya untuk mewujudkan masyarakat yang berdamai dengan masa lalunya. Hal ini dapat dilakukan baik melalui mekanisme yudisial, maupun non-yudisial, dengan keterlibatan dunia internasional, sesuai dengan tingkat kebutuhannya (atau tidak harus semuanya), dalam hal penuntutan pidana, penuntutan ganti rugi (reparasi), pengungkapan kebenaran, reformasi kelembagaan dan pemecatan dari jabatan pemerintahan yang didasarkan pada penyelidikan fakta, atau dengan mengkombinasikan langkah-langkah tersebut di atas. ${ }^{2}$

Sudah menjadi hukum sejarah bahwa setiap terjadi pelanggaran berat hak asasi manusia, genosida, kejahatan perang, pergantian rezim kekuasaan otoriter menjadi pemerintahan yang demokratis melalui revolusi atau reformasi selalu muncul permasalahan krisis kemanusiaan dan keadilan. Koeksistensi kekuasaan otoriter dengan korupsi politik menuntut adanya tindakan apa saja yang dapat

\footnotetext{
${ }^{1}$ Lihat Pasal 1 Undang-Undang Nomor 39 Tahun 1999 Tentang Hak Asasi Manusia.

2 Tosa Hiroyuki, Keadilan Transisional Yang Terabaikan, Tinjauan Ulang Masalah Indonesia Dan Timor-Timur. Kobe University, dalam http://www2.kobe-u.ac.jp/ tosa/keadilan.pdf
} 
memproteksi kelangsungan kekuasaan politik yang korup dan konglomerasi ekonomi yang mendukungnya. Olehnya itu, segala upaya untuk mempertahankan kekuasaan otoritarian berkelanjutan senantiasa berkorelasi dengan harga diri penguasa, loyalitas para pendukung, dan aset sosial ekonominya sehingga tindakan melanggar HAM oleh penguasa otoriter dengan berbagai corak dan variasinya akan menjadi jalan yang tidak bisa dielakkan. ${ }^{3}$

Konsekuensi logisnya, turbulensi kejahatan HAM yang terjadi menjadi masalah hukum dan kemanusiaan yang kompleks. Kejahatan berat HAM merupakan musuh seluruh umat manusia (hostis hominis generis) sehingga menjadi tanggung jawab bersama (erga omnes obligation) bagi rakyat, negara, dan masyarakat beradab internasional. Kejahatan berat HAM selalu menjadi mendung dan sisi gelap perjalanan bangsa. Memori kolektif masyarakat internasional dapat muncul dan mengasosiasikan kejahatan HAM oleh Hitler dengan Jerman, Jugun Ianfu dengan Jepang, genosida antara Tutsi versus Hutu di Rwanda, Serbia versus Herzegovina di bekas Yugoslavia, apartheid di Afrika Selatan, pembunuhan massal di Kamboja, dan lain sejenisnya. Untuk itu, utang sejarah dalam krisis kemanusiaan harus diselesaikan melalui transitional justice. Dalam upaya realisasi keadilan transisional selalu ada dua lembaga kembar yang lahir, yaitu Pengadilan HAM Ad Hoc atau tribunal dan Komisi Kebenaran dan Rekonsiliasi (KKR) atau Truth and Reconciliation Commission (TRC). ${ }^{4}$

Setelah tumbangnya berbagai rezim otoriter pada dekade 80-an di belahan dunia, topik yang menarik dalam diskursus HAM khususnya dalam konteks atau mekanisme pertanggungjawaban pelanggaran berat HAM masa lalu. dilatarbelakangi dari tuntutan reformasi yang menuntut perlunya proses penyelidikan terhadap berbagai pelanggaran berat HAM. Hal tersebut menjadi satu pijakan dengan lahirnya berbagai badan atau komisi seperti; komisi pencari fakta, komisi klarifikasi, komisi penyelidik atau lebih dikenal dengan sebutan Komisi Kebenaran dan Rekonsiliasi. Dalam konteks keadilan dimasa transisi, pengungkapan kebenaran menjadi kewajiban hukum rezim transisi. Demikian juga penghukuman (prosekusi) atau pengadilan (trial) bukan satu-satunya jalan untuk mempertanggungjawabkan kejahatan di masa lalu. ${ }^{5}$

Pasca runtuhnya rezim Orde Baru, terdapat beberapa perubahan di dalam konstitusi negara yang memiliki tujuan yaitu penetapan prinsip-prinsip kehidupan bernegara dan berbangsa yang demokratis, melakukan upaya pencegahan untuk mengantisipasi munculnya rezim yang sama seperti pada zaman otoriter dan represif, terjaminya Rule Of Law, serta diakui dan dihormatinya hak asasi dan kebebasan fundamental warga. Konstitusionalisme dalam masa-masa perubahan politik

\footnotetext{
3 HAM Keadilan Transisional, dalam website https://nasional.kompas.com/read/2015/07/30/15272881/HAM.dan. Keadilan.Transisional?page=all.

${ }^{5}$ Yohanes De Masinus Arus, (2003), The Right To Know The Truth, Kerangka Normatif Mengungkap Kebenaran, Dalam Pencarian Keadilan Di Masa Transisi, Cetakan Pertama, Elsam, Jakarta, hal.334
} 
memiliki kaitan "konstruktivis" dengan tatanan politik yang ada. ${ }^{6}$ Isu jaminan serta perlindungan terhadap hak asasi manusia menjadi hal yang sangat krusial untuk segera diterapkan. Tindakan ini baik yang sifatnya konkret maupun dalam bentuk perubahan konstitusi yang menjadi landasan berbagai aturan hukum dalam hal perlindungan HAM. Pemerintahan baru pada saat itu dituntut untuk segera mengambil kebijakan guna memulai langkah pemulihan dan peningkatan penghormatan, pemenuhan dan perlindungan HAM di Indonesia. Desakan untuk melakukan pembaharuan dalam rangka penegakan HAM menjadi hal yang sangat krusial, mengingat berbagai pelanggaran yang telah terjadi pada masa rezim sebelumnya, seperti kasus Tanjung Priok, kasus Timor Timur, kasus Kedung Ombo, pembunuhan massal ddan penangkapan tanpa proses hukum, penculikan aktivis pro demokrasi, serta berbagai pelanggaran HAM lainnya yang mana hal ini dilakukan dalam rangka semakin melanggengkan kekuasaan.

Pembentukan Komisi Kebenaran dan Rekonsiliasi dianggap perlu karena merupakan jawaban untuk menyelelesaikan masalah utama yang biasa menghalangi setiap penyelesaian pelanggaran HAM. Langkah pertama komisi akan mengatasi kemandegan penyelesaian pelanggaran HAM yang terjadi di masa lalu; kedua memberikan kesempatan kepada pada saksi maupun korban untuk mengungkap kebenaran sekaligus menjadi instrument pembelajaran bagi masyarakat tentang HAM; ketiga mengatasi kelemahan-kelemahan dalam peradilan HAM terkait efisiensi biaya. ${ }^{7}$ Menurut Mark Freeman komisi kebenaran adalah sebuah komisi penyelidikan yang ad hoc dan otonom, dan berpusat pada korban. ${ }^{8}$ Namun tak dapat dipungkiri di sisi lain Keadilan transisional selalu beririsan dengan subjek-subjek lain seperti amnesty, rekonsiliasi, dan pengawetan memori, juga demokratisasi, dan upaya perdamaian.

Walaupun arus demokrasi telah mengalir dengan cepat, demokrasi-demokrasi yang muncul masih menghadapi hambatan-hambatan yang menakutkan dalam menegakkan aturan-aturan hukum dan membentuk jaminan yang kokoh terhadap HAM. Problematika yang dihadapi oleh negara yang baru demokratis adalah bagaimana mereka harus memperlakukan pihak-pihak yang telah bersalah melakukan berbagai kejahatan tersebut dalam rezim yang lama. Kesulitan yang muncul dalam mencapai suatu solusi yang adil yang dapat diterima oleh masyarakat yang telah lama menderita. ${ }^{9}$ Hal lain yang mewarnai keadilan transisi adalah

\footnotetext{
${ }^{6}$ Suparman Marzuki, (2012), Pengadilan Ham Di Indonesia, Cetakan Pertama, Airlangga, Jakarta, hal. 21

7 Eko Prasetyo, (2001), HAM Kejahatan Negara Dan Imprealisme Modal, Cetakan Pertama, Pustaka Pelajar, Yogyakarta, hal. 222

${ }^{8}$ Mark Freeman, (2008), Komisi-Komisi Kebenaran Dan Kepatutan Procedural, Penerjemah Wibowo dkk dari Truth Commission And Procedural Fairness, Cetakan Pertama, Elsam, Jakarta, hal. 5-6

9 Satya Arinanto, (2005), Hak Asasi Manusia Dalam Transisi Politik Di Indonesia, Cetakan Kedua, Pusat Studi Hukum Tata Negara, Jakarta, hal. 56
} 
menwujudkan keadilan di era transisi guna mengantarkan kehidupan masyarakat, bangsa, dan negara menuju demokrasi di masa depan.

Di Indonesia sendiri, secara konstitusional dan yuridis terikat untuk mematuhi ketentuan tentang HAM. Di samping itu, telah dengan tegas jaminan perlindungan HAM tertuang dalam Pancasila, yaitu kemanusiaan yang adil dan beradab, dan Undang-Undang Dasar Negara Republik Indonesia tahun 1945, Undang-Undang Nomor 39 Tahun 1999 tentang Hak Asasi Manusia, Undang-Undang Nomor 26 Tahun 2000 tentang Pengadilan HAM yang mengadopsi Statuta Roma, dan konvensi internasional lain. Indonesia juga telah meratifikasi International Covenant on Civil and Political Rights (ICCPR) atau kovenan hak-hak sipil dan politik melalui UndangUndang Nomor 12 Tahun 2005, di mana dalam Pasal 2 Ayat (3) menentukan bahwa setiap negara pihak kovenan ini berjanji untuk menjamin bahwa setiap orang yang hak-haknya atau kebebasan-kebebasannya yang diakui kovenan ini dilanggar harus memperoleh ganti rugi yang efektif meskipun pelanggaran dilakukan oleh orangorang yang memegang jabatan resmi.

Penyelesaian perkara HAM melalui jalur prosekutorial menuntut adanya pemenuhan prosedur hukum acara, mulai dari penyelidikan, penyidikan, penuntutan dan proses di pengadilan tingkat pertama, banding, kasasi, dan peninjauan kembali. Dengan demikian, penyelesaian perkara pidana atau kejahatan HAM melalui KKR merupakan konsekuensi etis dari adanya keterbatasan hukum. Dari banyak faktor yang memberi kontribusi adanya keterbatasan hukum, terutama dalam penegakan hukum HAM, masalah political will menjadi determinan. Apalagi dalam konteks proses peradilan HAM ad hoc di Indonesia yang menuntut adanya ketersediaan profesionalisme para penegak hukum, baik penyidik, penuntut umum, hakim, maupun penasihat hukum. Berdasarkan hal tersebut, penelitian ini mencoba menjawab permasalahan mengenai peranan Keadilan Transisional (Transitional Justice) dalam menangani kasus pelanggaran HAM berat di Indonesia.

\section{Metode}

Dalam penulisan artikel ini digunakan metode penelitian hukum yaitu dengan pendekatan normatif yuridis. Adapun pendekatan normatif yuridis dengan mengacu pada norma-norma hukum yang mengenai perlindungan Hak Asasi Manusia, secara khsusus terkait dengan Transitional Justice. Data yang digunakan dalam artikel ini adalah data sekunder berupa bahan hukum primer dan bahan hukum sekunder. Bahan hukum sekunder diambil melalui berbagai peraturan mengenai Hak Asasi Manusia, yaitu Undan-Undang Nomor 39 Tahun 1999 tentang Hak Asasi Manusia, Undang-Undang Nomor 20 Tahun 2000 tentang Pengadilan HAM dan berbagai peraturan lainnya. Bahan hukum sekunder yang digunakan adalah literatur berupa buku, jurnal, dan artikel terkait. Analisis data dalam artikel ini menggunakan analisis 
kualitatif dengan mendeskripsikan fakta-fakta yang ada, kemudian dilakukan analisis berdasarkan norma hukum dan teori yang ada.

\section{Konsep Transitional Justice}

Menurut "International Center For Transitional Justice", transisional justice atau keadilan transisi diartikan sebagai Responses To Systematic Or Widespread Violation Of Human Rights yang berarti adalah tanggapan kongkrit terhadap pelanggaran HAM yang bersifat massif dan/atau meluas yang pada intinya pelanggaran hak asasi yang bersifat massif dan/atau meluas masuk dalam kategori. Implikasi konsep transitional justice yaitu keadilan yang mencoba keluar dari pakem klasik dengan tokoh Aristoteles. ${ }^{10}$ Terdapat dua konsep keadilan yaitu keadilan distributif dan korektif dan juga konsep keadilan yang dikemukakan oleh Jhon Rawls yakni keadilan di atas kesetaraan (Justice As Fairness) yang hanya dapat direalisasikan dalam kondisi normal.

Keadilan transisi terdiri dari beberapa konsep yaitu keadilan pidana atau kriminal yang mengedepankan penghukuman, dapat juga berupa keadilan histori yang merupakan bentuk keadilan yang ingin membongkar sejarah, keadilan administratif yang merupakan pembenahan serta pembersihan sistem penyelenggara negara, keadilan reparatoris yang mengedepankan hak-hak korban dengan memberikan kompenisasi, restitusi, dan rehabilitasi, dan keadilan konstitusional yang ditegakkan di atas prinsip Rule Of Law, kedaulatan rakyat atau legitimasi demokratis yang mengedepankan hukum. ${ }^{11}$

Menurut Ruti G Tietel, keadilan transisi merupakan upaya penegakan keadilan di masa transisi. Adapun dari lima keadilan yang telah dijabarkan pada paragraph di atas, yaitu Pertama, Keadilan Pidana seringkali dikaitkan dengan pengadilan dan penghukuman penguasa sebelumnya dengan cara bertanggung jawab atas apa yang telah dilakukan rezim tersebut. Keadilan pidana merupakan keadilan yang menggunakan peradilan pidana untuk mencapai suatu keadilan dengan cara penghukuman bagi pelaku pelanggaran HAM masa lalu. Dalam konteks ini, pelaksanaan peradilan pidana dianggap merupakan cara terbaik untuk memperbaiki "keadilan" negara dimasa lalu dan memajukan transformasi normative kesistem yang taat kedaulatan hukum. ${ }^{12}$ Kedua, Keadilan Historis merupakan proses dari masyarakat transisi untuk mengadakan penyelidikan tentang sejarah dan pertanggungjawabannya. Penyelidikan dan narasi sejarah ini memainkan peran penting dalam transisi dari masa lalu ke masa kini. ${ }^{13}$ Dimana masa lalu suatu rezim

\footnotetext{
10 Teguh Prasetyo dan Abdul Halim Barakatullah, (2007), Ilmu Hukum Dan Filsafat Hukum, Cetakan Kedua, Pustaka Pelajar, Yogyakarta, hal. 60-61

11 Herry Sucipto Dan Harjianto Tohari, (2012), Penanganan Pelanggaran berat HAM Masa Lalu, Dalam Penyelesaian Pelanggaran berat HAM Masa Lalu, Jurnal Dignitas, v8n1, hal. 80

12 Ruti G Teitel, (2004), Keadilan Transisi, Sebuah Tinjauan Analitis-Komprehensif, Terjemahan Elsam Dari Transisional Justice, Cetakan Pertama, Elsam, Jakarta, hal. 23

13 Ibid, hal. 7
} 
dengan segala bentuk tindakan represif pengabaian atas HAM bukan sekedar masa lalu dalam pengertian waktu tetapi proses berpikir yang sangat penting artinya bagi tatanan sosial politik suatu bangsa kedepan. Mengungkap kebenaran suatu peristiwa kemanusiaan yang terjadi pada rezim sebelumnya adalah keadilan yang harus diungkap dan diketahui sebagai pelajaran. ${ }^{14}$ Ketiga, Keadilan Reparatoris atau Reparasi merupakan keadilan yang fokus pada proses perbaikan kesalahan yang telah dilakukan oleh rezim sebelumnya yang memandang kebelakang yang merujuk pada kesalahan rezim dimasa lalu. Istilah keadilan reparatoris ini memiliki dimensi yang luas yang mencakup pemulihan, ganti rugi material, pengembalian nama baik, kompenisasi, restitusi rehabilitasi dan pemberian tanda mata. ${ }^{15}$ Keempat, Keadilan Administratif merupakan pelengkap dari keadilan pidana yang secara tradisional ditujukan pada penjatuhan hukuman kepada pelaku. Keadilan pidana juga bisa gagal menghukum pelaku dan akibatnya pihak yang bersalah masih bisa memegang kekuasaan dalam rezim yang baru, atau dengan kata lain penerapan keadilan administrasi merupakan tindakan penyingkiran yang secara sistematis mendiskualifikasikan kelompok-kelompok tertentu, khususnya yang terlibat dalam pemerintahan rezim otoriter secara keseluruhan dari pemerintahan yang baru. ${ }^{16}$ Kelima, Keadilan Konstitisional memiliki peran transformative dalam konstitusi di masa-masa perubahan atau reformasi yang telah terjadi. ${ }^{17}$

Secara sederhana konsep keadilan transisional yang dikemukakan oleh Ruti G. Teitel, di mana masalah keadilan transisional timbul dalam konteks transisi atau suatu perubahan dalam tataran politik. ${ }^{18}$ Jadi masalah keadilan transisional timbul pada jangka waktu antara dua sistem pemerintahan. Pemahaman umum tentang transisi mengandung makna normatif, yaitu adanya pergeseran rezim dari kurang demokratis menjadi lebih demokratis. Kemudian lebih lanjut oleh Teitel dikatakan bahwa fenomena transisi mengarah pada kaitan erat dalam pergeseran normatif tentang pemahaman keadilan dan peran hukum dalam konstruksi transisi.

Makna kata keadilan dalam keadilan Transisional adalah tidak berdiri sendiri sebagaimana yang juga menjadi tujuan hukum. Akan tetapi pemenuhan keadilan yang berkaitan dengan masa transisi suatu pemerintahan negara dari pemerintahan yang otoriter ke pemerintahan demokratis. Hal ini secara jelas digambarkan bahwa fenomena transisional adalah fenomena yang tidak biasa atau tidak normal yang menawarkan cara pandang baru yang melampaui teori-teori klasik seputar keadilan, demokrasi, peran dan hakikat hukum, negara dan masyarakat. Adanya makna baru yang ditemukan untuk persoalan keadilan di masa transisi dan peran hukum dalam penegakan keadilan di masa transisi itu. Sesuai pandangan Teitel tentang konsep

\footnotetext{
${ }^{14}$ Suparman Marzuki, Op.cit, hal. 20

${ }^{15}$ Ibid

${ }^{16}$ Ibid

${ }^{17}$ Ruti G Teitel, Op.cit, HIm 7

18 Ibid, 5-7.
} 
transitional justice yang memproposalkan teori keadilan transisional dan teori hukum transisional yang disebut yurisprudensi transisional. Hal ini harus dilakukan karena suasana transisi berarti dibayangi adanya kekerasan masa lalu dan adanya keinginan meraih harapan akan tatanan sosial yang adil dan damai di masa depan. Harapan mewujudkan keadilan transisional, agar pemerintahan baru di masa transisi dapat berjalan dengan baik dan tidak dibebankan oleh persoalan atau kasus-kasus HAM) yang pernah terjadi. Oleh karena itulah penyelesaian kasus masa lalu harus diselesaikan dalam perspektif keadilan transisional.

Mengenai konsep atau pengertian transitional justice ini juga dikemukakan berkaitan dengan tantangan yang dihadapi oleh suatu negara transisional yang dalam proses keluar dari pemerintahan otoriter represif ke pemerintahan yang lebih demokratis. Penjabaran konsep transitional justice ini berhubungan dengan penghormatan kembali hak-hak sipil, politik, ekonomi, sosial dan budaya yang sebelumnya secara sistematis ditindas.

Lebih lanjut, dari beberapa pengalaman negara-negara lain, seperti Afrika Selatan, El Salvador dan Argentina, transisitional justice dilakukan melalui pengungkapan kebenaran (truth finding) atas semua bentuk pelanggaran HAM masa silam yang dikategorikan sebagai crime against humanity. Selain pelaku pelanggaran HAM tersebut diproses, diadili dan dihukum juga banyak yang diberikan amnesti. Khusus keadilan para korban dilakukan rehabilitasi melalui berbagai cara sebagai sebuah healing process seperti proses melalui komisi kebenaran dan keadilan. Intinya transitional justice ingin menghapus mata rantai impunity melalui proses truth finding, healing process dan rekonsiliasi dengan mengawinkan proses hukum, amnesti, rehabilitasi dan rehabilitasi demokrasi.

Adanya konsep penyelesaian kasus pelanggaran HAM dengan tidak mengedepankan proses pengadilan semata, tetapi mengkombinasikan dengan jalan pengungkapan kebenaran juga dikemukakan oleh Ifdal Kasim. Menurut Ifdal Kasim, kedua proses penyelesaian ini tidak sama sekali terpisah satu dengan lainnya. Pengungkapan kebenaran hakikatnya menegaskan kembali keabsahan norma-norma yang selama ini telah dilanggar. ${ }^{19}$ Dalam konteks ini dibutuhkan pengakuan bersalah dari pelaku (institusi negara/militer), dan diikuti dengan permintaan maaf secara resmi. Pengakuan bersalah ini membawa implikasi yang jauh lebih penting ketimbang menghukum lima belas perwira di antara ratusan perwira. Oleh karena walaupun dihukum ia akan bebas kembali, tetapi mereka tidak mau mengakui kesalahannya, sehingga penghukuman tidak membawa penegasan keabsahan norma yang dilanggar. Berbeda dengan pengakuan bersalah dan permintaan maaf yang harus pula diikuti oleh pemulihan kembali para korban dengan jalan memberikan kompensasi, rehabilitasi, atau bahkan jaminan bagi tidak terulangnya pelanggaran di

19 Ifdal Kasim dan Riyadi Terre, ed, (2003), Pencarian Keadilan di Masa Transisi, Elsam, Jakarta, hal. 29- 30. 
masa depan. Kalau jalan pemulihan para korban ini tidak ditempuh, maka pengakuan bersalah dan permintaan maaf negara tersebut menjadi kehilangan makna

\section{Peranan Konsep Keadilan Transisional (Transitional Justice) dalam Menangani Pelanggaran HAM Berat di Indonesia}

Telah dikemukakan sebelumnya bahwa konsep pelaksanaan transitional justice tidak telepas dari penegakan hukum terhadap pelanggaran HAM berat. Semenjak masa-masa awal era reformasi di Indonesia, di kalangan masyarakat telah muncul tuntutan agar para pelanggar HAM berat diadili. Seperti diketahui pada saat rezim Orde Baru memimpin telah terjadi beberapa pelanggaran HAM yang telah ditimbulkan baik yang bersifat vertikal (yang dilakukan oleh aparat negara terhadap warga negara) maupun horizontal (antar warga negara sendiri) dan tidak sedikit masuk dalam kategori gross violation of human rights. Hal tersebut tercermin dari kejadian berupa penangkapan yang tidak sah, penculikan, penganiyaan, perkosaan, penghilangan paksa, bahkan pembunuhan, pembakaran rumah tinggal dan tempat ibadah penyerangan pemuka agama beserta keluarganya.

Selain itu, terjadi pula penyalagunaan kekuasaan oleh pejabat publik dan aparat negara yang seharusnya menjadi penegak hukum, pemeliharaan keamanan, dan perlindungan rakyat, tetapi justru mengintimidasi, menganiaya, menghilangkan paksa dan atau menghilangkan nyawa. ${ }^{20}$ Terkait pelanggaran HAM masa lalu di Indonesia, sesungguhnya bukanlah hanya terjadi di Tahun 1998. Akan tetapi, dari hasil penyelidikan Komnas HAM, disimpulkan bahwa kategori kejahatan terhadap kemanusiaan itu terjadi beberapa kali dengan tempat dan tenggang waktu yang berbeda. Seperti yang terjadi dalam peristiwa pembantaian PKI pada Tahun (19651966), Tanjung Priok (1984), Talang Sari, Lampung (1989), penghilangan orang secara paksa (1997-1998), kerusuhan Mei (1998), Trisakti (1998), Semanggi I (1998) dan Semanggi II (1999), Timor-Timur (1999). ${ }^{21}$ Rangkaian masa lalu merupakan wujud dari sebuah rezim otoriter.

Peristiwa pembantaian Partai Komunis Indonesia atau disingkat PKI dilatarbelakangi atas dasar tuduhan bahwa PKI dalang dari pembunuhan tujuh perwira jendral, yang terjadi pada tanggal 30 September 1965 dikenal dengan peristiwa G30S/PKI. Akibat dari gerakan tersebut dikeluarkannya kebijakan negara untuk meniadakan partai tersebut dan diikuti dengan tindakan kekerasan terhadap warga negara yang dituduh sebagai anggota maupun simpatisan PKI. Tindakan

\footnotetext{
${ }^{20}$ Lihat Penjelasan Atas Undang-Undang Nomor 39 Tahun 1999 Tentang Hak Asasi Manusia Paragraph 6

${ }^{21}$ Rival Mainur, Kebijakan Negara Dalam Penyelesaian Pelanggaran Ham Masa Lalu Melalui Perspektif Penal Dan Non Penal, Makalah Di Sampaikan Dalam Ruang Kuliah, Program Pasca Sarjana, Fakultas Hukum Universitas Islam Indonesia, Jogjakarta 20 November 2014.
} 
tersebut dilakukan dengan cara-cara represif yang berdampak pada jatuhnya korban jiwa maupun luka-luka. ${ }^{22}$

Tindak kekerasan yang dilakukan terhadap anggota PKI maupun yang diduga sebagai simpatisan menjadi lembar sejarah hitam bangsa ini. Karena peristiwa tersebut terindikasi telah terjadi diberbagai wilayah tanah air diantaranya; pembunuhan di Maumere (Nusa Tenggara Timur), penyiksaan di LP Perkambingan (Denpasar), penghilangan orang secara paksa di Bingin Teluk (Sumatera Selatan), perbudakan di Kamp Moncongloe Makassar (Sulawesi Selatan), perbudakan di Pulau Buru (Maluku) dan pembunuhan dan penghilangan orang secara paksa di tempat penahanan jalan Ghandi di Medan (Sumatera Utara). ${ }^{23}$

Pada masa rezim Orde Baru pelanggaran HAM maupun kejahatan lainnya terhadap kemanusiaan telah menjadi kultur atas upaya pelanggengan kekuasaan. Penguasa Orde Baru menggunakan kekerasan dalam membungkam perlawanan, untuk menjalankan kebijakan ekonomi dan mempertahankan kekuasaan. Berawal dari pembasmian gerakan kiri pertengahan 1960-an rangkaian kekerasan kemudian melanda sektor-sektor masyarakat lainnya: gerakan nasionalis pendukung Soekarno, komunitas muslim yang menolak asas tunggal pancasila, gerakan mahasiswa, aktivis buru, petani dan sampai pada perjuangan pengitegrasian di Timor Leste. ${ }^{24}$

Meskipun rezim Orde Baru (Soeharto) telah runtuh dan berganti ke rezim yang konon katanya lebih demokratis, namun pada sisi lain, keluarga korban pelanggaran HAM menuntut kepada pemerintah agar menyelesaikan kasus pelanggaran HAM masa lalu dan memberikan keadilan bagi mereka yang telah menjadi korban. Keadilan yang telah didambakan oleh para korban adalah keadilan transisional (transisional justice). ${ }^{25}$

Sejak masa reformasi hingga saat ini, masalah pelanggaran HAM belumlah terselesaikan hingga tuntas. Dua mekanisme penyelesaian penegakan hukum melalui pembentukan pengadilan HAM yang bersifat ad hoc ternyata tidak bisa memberikan rasa keadilan kepada masyarakat korban. Di sisi lain pengalaman diberbagai negara dapat dijadikan contoh, karena ketika satu jalan tidak berhasil, maka upaya pencapaian keadilan dengan beragam jalur bisa dilakukan. Hasilnya, sejumlah kemenangan bisa diraih, meski berkorban waktu yang cukup lama. Hal ini menegaskan bahwa tidak ada jalan tunggal dalam penyelesaian pelanggaran HAM masa lalu. ${ }^{26}$

\footnotetext{
22 Ringkasan Eksekutif, Laporan Penyelidikan Pelanggaran Ham Yang Berat (Jakarta : Komnas HAM, Tanpa Tahun), hal.3

${ }^{23}$ Ibid., hal. 5-15

${ }^{24}$ Hilmar Farid dan Riikardo Simarmata, 2004, Demi Kebenaran, Pemetaan Upaya-Upaya Pencarian Keadilan Dalam Masa Transisi Di Indonesia, Cetakan Pertama, Elsam, Jakarta, hal. 15

${ }^{25}$ Agus Raharjo, (2007), Implikasi Pembatalan Undang-Undang Komisi Kebenaran dan Rekonsiliasi Terhadap Prospek Penanganan Pelanggaran Berat Hak Asasi Manusia. Jurnal Mimbar Hukum, v19n1, 2007, hal 2.

${ }^{26}$ Elsam, (2012), Penyelesaian Pelanggaran Ham Masa Lalu, Mendorong Inisiatif Masyarakat Sipil, Memastikan Negara Bertanggung Jawab, Kertas Posisi Keadilan Transisional 3, Elsam, Jakarta, hal. 1
} 
Undang-Undang Nomor 26 Tahun 2000 tentang Pengadilan HAM saat ini menjadi pijakan dasar pemerintah Indonesia dalam rangka penyelesaian pelanggaran HAM masa lalu. Kehadiran pengadilan HAM ad hoc merupakan wujud untuk menuntut pertanggungjawaban individual atas rangkaian pelanggaran HAM masa lalu. Begitu banyak kasus pelanggaran HAM sebelum dan sesudah dikeluarkannya Undang-undang Pengadilan HAM, akan tetapi faktanya dari kasus-kasus pelanggaran HAM yang pernah ditangani dan diselesaikan melalui pengadilan HAM di bawah tahun 2000, baru dua kasus yakni Pelanggaran HAM yang terjadi di TimorTimur dan Tanjung Priok ditangani oleh pengadilan HAM yang bersifat Adhoc di Jakarta. ${ }^{27}$

Untuk mendorong akuntabilitas hukum atas berbagai kasus pelanggaran HAM masa lalu, maka perlu adanya upaya untuk membentuk suatu lembaga penyelesaian pelanggaran HAM yaitu Komisi Kebenaran dan Rekonsiliasi. Pembentukan Komisi Kebenaran dan Rekonsiliasi sebagaimana pengalaman di beberapa negara, yang mana berada dalam masa transisi suatu pemerintahan. Pembentukan Undang-Undang Nomor 27 Tahun 2004 tentang Komisi Kebenaran dan Rekonsiliasi berorientasi pada proses pencarian sebuah kebenaran dan memberikan keadilan bagi korban melalui jalur Non Yudisial.

Penyelesaian pelanggaran HAM Berat tidak hanya dapat diselesaikan melalui mekanisme Pengadilan baik pengadilan HAM permanen maupun Ad Hoc. Di dalam Undang-Undang Pengadilan HAM terdapat ketentuan penyelesaian pelanggaran HAM Berat melalui mekanisme non pengadilan yaitu melalui Komisi Kebenaran dan Rekonsiliasi (KKR). Penyelesaian kasus pelanggaran melalui KKR biasa dilakukan dalam kondisi pemerintahan transisional. Suatu peralihan pemerintahan dari sistem otoriter atau represif ke suatu sistem negara yang mengembangkan prinsip-prinsip demokrasi. Tuntutan keadilan bagi korban pelanggaran HAM masa lalu yang ingin dicapai dalam suatu peralihan pemerintahan seperti inilah yang biasa diistilahkan dengan transitional justice.

Namun, harapan tersebut sirna setelah Undang-Undang KKR, sudah dinyatakan tidak berlaku lagi oleh Mahkamah Konstitusi (MK). Putusan MK ini berdasarkan pengajuan judicial review yang dilakukan oleh Tim Advokasi Kebenaran dan Keadilan terhadap beberapa pasal dalam UU KKR ini (Pasal 1 angka 9, Pasal 27, dan Pasal 44) yang dianggap bertentangan dengan UUD NRI Tahun 1945. Akan tetapi MK dalam putusannya malah menganggap bahwa materi Undang-Undang U KKR ini saling bertentangan. Tidak ada kepastian hukum dalam norma Undang-Undang KKR sehingga tidak mungkin dapat mengungkap kebenaran dan melakukan rekonsiliasi. Oleh karena itu MK menilai Undang-Undang KKR secara keseluruhan

\footnotetext{
${ }^{27}$ Binsar Gultom, (2010), Pelanggaran HAM Dalam Hukum Keadaan Darurat Di Indonesia, Cetakan Pertama, Gramedia Pustaka Utama, Jakarta, hal. 271
} 
bertentangan dengan UUD NRI Tahun 1945, sehingga harus dinyatakan tidak mempunyai kekuatan mengikat lagi.

Sebagaimana pengalaman yang dilakukan oleh beberapa negara, pada hakikatnya Komisi Kebenaran dapat membawa rasa keadilan terhadap korban apabila dijalankan secara independen. Artinya negara harus mengungkap dan menjelaskan serta mempertanggungjawabkan tindakan-tindakan di masa lampau, baik yang dilakukan oleh pemerintah yang sementara berkuasa maupun yang dilakukan oleh rezim sebelumnya, berkaitan dengan korban-korban dan pelakupelaku kejahatan. Kemudian dilakukan rekonsiliasi, artinya setiap masyarakat yang menjadi korban tindakan represif harus dipulihkan dari pengalaman masa lampaunya, serta mencapai kesepakatan mengenai syarat-syarat penyelesaian substansial dari sebuah konflik dan kekacauan yang terjadi.

Indonesia sebagai Negara yang mempunyai predikat sebagai Negara yang menjunujung tinggi nilai - nilai kemanusiaan harus mampu menyelesaikan beban sejarah kasus HAM yang terjadi. Untuk itu, utang sejarah dalam krisis kemanusiaan harus diselesaikan melalui transitional justice. Dalam upaya realisasi keadilan transisional selalu ada dua lembaga kembar yang lahir, yaitu Pengadilan HAM Ad Hoc atau tribunal dan Komisi Kebenaran dan Rekonsiliasi (KKR) atau Truth and Reconciliation Commission (TRC). Harus dicatat bahwa hubungan dua lembaga kembar tersebut bersifat pelengkap (complement), bukan pengganti (substitute). Dengan demikian, proses hukum di Pengadilan HAM Ad Hoc tidak menegasikan proses rekonsiliasi dan sebaliknya.

Penyelenggaraan Pengadilan HAM Ad Hoc merupakan upaya pencerahan atas sisi gelap perjalanan bangsa agar pembangunan negara tidak tersandera oleh masa lalu. Penyelesaian kejahatan HAM yang berkualifikasi most serious crimes melalui penuntutan ke pengadilan sering mengalami keterbatasan untuk mewujudkan keadilan. Namun, hal itu harus tetap dilaksanakan untuk menegakkan martabat bangsa. Belajar dari apa yang telah dilaksanakan di Afrika Selatan, Amerika Latin, Sierra Leone, Kamboja, dan lain sejenisnya, negara kita Indonesia dituntut untuk mencerahkan mendung kasus HAM berat masa lalu. Untuk itu, kelahiran Pengadilan HAM Ad Hoc biasanya yang memberlakukan ex post facto law atau hukum yang bersifat retroaktif, harus dipahami secara kolektif bahwa transisional justice adalah

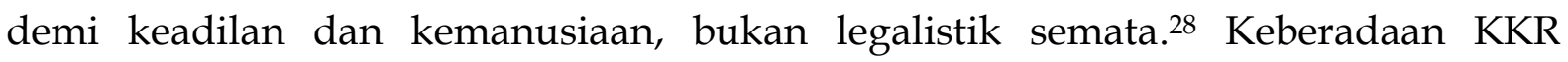
ditujukan untuk mewujudkan restorative justice atau total justice guna membangun kembali ekuilibrium metafisik dan relasi sosial kehidupan korban kejahatan HAM dan/atau keluarganya, lingkungan masyarakatnya, para pemangku kepentingan, juga pelaku kejahatan. Dengan adanya upaya restoratif tersebut, gairah kehidupan sosial akan berpendar kembali dan dapat membangun peradabannya.

$\begin{array}{lcccc}28 & \text { dan } & \text { Keadiloan } & \text { Transisional, } & \text { dalam } \\ \text { https://nasional.kompas.com/read/2015/07/30/15272881/HAM.dan. Keadilan.Transisional?page=all. } & \text {, }\end{array}$ 
Untuk menuntaskan permasalahan pelanggaran HAM berat masa lalu terkhusus di Indonesia, kemauan dan keberanian politik yang kuat dari pemerintah dan dukungan masyarakat mutlak diperlukan. Hal ini karena pengungkapan dan penuntasan pelanggaran HAM di negeri yang baru lepas dari belenggu pemerintahan yang otokratik adalah pekerjaan maha berat yang dipastikan akan mendapat resistensi dari pihak-pihak yang berkepentingan agar pelanggaran HAM masa lalu tetap tak tersentuh. Legitimasi dari rakyat adalah modal yang harus dimanfaatkan untuk terus mengadakan penyelidikan dan tindakan tindakan penyelesaian baik melalui Pengadilan HAM ad hoc maupun melalui Komisi Kebenaran dan Rekonsiliasi. $^{29}$

\section{Komisi Kebenaran dan Rekonsiliasi Sebagai Wujud Transitional Justice}

Kehadiran Komisi Kebenaran dan Rekonsiliasi di Indonesia merupakan kebutuhan mendesak yang sangat didambakan masyarakat demi terwujudnya rekonsiliasi (rujuk, kerukunan) nasional, guna membangun masyarakat demokratis berdasarkan nilai-nilai yang terkandung dalam Pancasila dan Pembukaan NRI Tahun UUD 1945, yang menjunjung tinggi supremasi hukum dan penghormatan terhadap hak asasi manusia (HAM). ${ }^{30}$ Upaya pembentukan KKR Indonesia merupakan konsekuensi dari amanat reformasi dalam kerangka demokratisasi yang antara lain tidak terlepas dari upaya bangsa Indonesia untuk memajukan dan melindungi HAM, sebagaimana tertuang dalam TAP MPR No. XVII/MPR/1998 tentang HAM. Sebagai perwujudan dari komitmen bangsa untuk pemajuan dan perlindungan HAM, kemudian dirumuskan pula Rencana Aksi Nasional (RAN) HAM yang disusul dengan langkah ratifikasi berbagai konvensi HAM internasional (antara lain, Konvensi Anti Penyiksaan dan Konvensi Penghapusan Diskriminasi Ras). ${ }^{31}$

KKR memang tidak menggantikan pengadilan dan sesungguhnya tidak pernah dimaksudkan untuk menggantikannya. Lembaga ini dihadirkan karena kesadaran akan adanya masalah yang serius yang melakat pada sistem peradilan umum dalam menyelesaikan kejahatan terhadap HAM, apalagi bila peristiwanya terjadi pada masa lalu dan terjadi dalam skala yang amat luas, dan sistemik. Dengan kata lain, kehadiran KKR sebenarnya merupakan pengakuan diam-diam bahwa sistem peradilan umum tak dapat diharapkan terlalu banyak untuk menyelesaikan berbagai kejahatan terhadap, ${ }^{32}$ HAM yang pengoperasian nya berada dalam wilayah pengaruh politik. Kenyataan ini memang tampak menyakitkan.

\footnotetext{
${ }^{29}$ Manunggal K. Wardaya, “Menanti Keadilan: Urgensi Penyelesaian Masalah Pelanggaran HAM Berat Masa Lalu Di Ujung Masa Transisi”

$30 \mathrm{lbid}$

$31 \mathrm{lbid}$

32 Carl Joachim Friedrich, (2004), The Philosophy of Law in Historical Perpective, Filasafat Hukum, Perpektif Historis, alih bahasa Raisul Muttaqien, cet. Ke-1, Penerbit Nusa dan Penerbit Nusamedia, Bandung, hal. 239.
} 
KKR jelas dapat menawarkan terobosan yang berarti jika institusi ini dapat menjembatani kesenjangan itu. Selain itu, institusi ini barulah dapat dianggap bermanfaat apabila mampu mendamaikan prinsipprinsip kebenaran dan keadilan di satu pihak, dan kebutuhan untuk menyongsong masa depan yang lebih berpengharapan melalui usahausaha yang diprakarsai bersama. KKR hanya akan berguna apabila ia dapat menawarkan jalan keluar dari terowongan panjang berlikuliku tanpa akhir. KKR hanya mungkin membantu para korban berdamai dengan masa lalunya dan pelakunya untuk bertobat apabila terdapat kepercayaan kolektif bahwa lembaga ini memang diniatkan untuk menyelamatkan masa depan dengan cara menarik garis yang jelas antara masa lalu dan masa depan. Itulah yang mungkin untuk sebagian dikandung dalam makna keadilan transisional.

Apapun hasilnya, KKR di Indonesia harus mampu melahirkan sebuah kesadaran baru tentang pentingnya semua orang di negeri mengerti satu hal, yaitu jangan ada lagi hal buruk dalam kehidupan hak-hak asasi manusia di negeri ini seperti yang kita, alami pada masa lalu. KKR memang mempunyai banyak keterbatasan dan kekurangan dalam gagasan maupun didalam implementasinya. Walaupun demikian, KKR di negeri ini harus mampu menjangkau lebih dari sekedar institusi yang berbasis moralitas hak asasi manusia. KKR semestinya diselenggarakan justru untuk menegaskan pesan sejarah yang amat penting bagi generasi mendatang, yakni the future of never again.

\section{Kesimpulan}

Konsep Keadilan Trasisional (Transitional Justice) dalam penanganan pelanggaran HAM berat bukanlah berperan untuk menggantian pengadilan, namun konsep ini dihadirkan karena kesadaran akan adanya masalah yang serius yang melekat pada sistem peradilan umum dalam menyelesaikan kejahatan terhadap HAM apalagi bila peristiwanya terjadi pada masa lalu dan terjadi dalam skala yang amat luas, dan sistemik. Dengan kata lain, konsep trasitional justice sebenarnya merupakan pengakuan diam-diam bahwa sistem peradilan umum tak dapat diharapkan terlalu banyak untuk menyelesaikan berbagai kejahatan terhadap HAM. Di satu sisi, kehadiran konsep Keadilan Trasisional (Trasitional Justice) di Indonesia merupakan kebutuhan mendesak yang sangat didambakan masyarakat demi terwujudnya rekonsiliasi (rujuk, kerukunan) nasional, guna membangun masyarakat demokratis berdasarkan nilai-nilai yang terkandung dalam Pancasila dan Pembukaan UUD NRI Tahun 1945, yang menjunjung tinggi supremasi hukum dan penghormatan terhadap Hak Asasi Manusia. 


\section{REFERENSI}

Agus Raharjo, (2007), Implikasi Pembatalan Undang-Undang Komisi Kebenaran dan Rekonsiliasi Terhadap Prospek Penanganan Pelanggaran Berat Hak Asasi Manusia. Jurnal Mimbar Hukum, v19n1.

Binsar Gultom, (2010), Pelanggaran HAM Dalam Hukum Keadaan Darurat Di Indonesia, Cetakan Pertama, Jakarta : Gramedia Pustaka Utama.

Carl Joachim Friedrich, (2004). The Philosophy of Law in Historical Perpective, Filasafat Hukum, Perpektif Historis, alih bahasa Raisul Muttaqien, cet. Ke 1, Bandung: Penerbit Nusa dan Penerbit Nusamedia.

Eko Prasetyo, (2001), HAM Kejahatan Negara Dan Imprealisme Modal, Cetakan Pertama, Yogjakarta: Pustaka Pelajar.

Elsam, (2012), Penyelesaian Pelanggaran Ham Masa Lalu, Mendorong Inisiatif Masyarakat Sipil, Memastikan Negara Bertanggung Jawab, Kertas Posisi Keadilan Transisional 3, Jakarta: Elsam.

Herry Sucipto dan Harjianto Tohari, (2012), Penanganan Pelanggaran berat HAM Masa

Lalu, Dalam Penyelesaian Pelanggaran berat HAM Masa Lalu, Jurnal Dignitas, v8n1. Hilmar Farid dan Riikardo Simarmata, (2004), Demi Kebenaran, Pemetaan Upaya-Upaya

Pencarian Keadilan Dalam Masa Transisi Di Indonesia., Cetakan Pertama, Jakarta : Elsam.

Ifdal Kasim \& Riyadi Terre, (2003), Pencarian Keadilan di Masa Transisi, Jakarta: Elsam. Manunggal K. Wardaya, Menanti Keadilan: Urgensi Penyelesaian Masalah Pelanggaran HAM Berat Masa Lalu Di Ujung Masa Transisi.

Mark Freeman, (2008), Komisi-Komisi Kebenaran Dan Kepatutan Procedural. Penerjemah

Wibowo, Dkk dari Truth Commission And Procedural Fairness, Cetakan Pertama, Jakarta: Elsam.

Ringkasan Eksekutif, Laporan Penyelidikan Pelanggaran Ham Yang Berat, Jakarta : Komnas HAM.

Rival Mainur, (2014), Kebijakan Negara Dalam Penyelesaian Pelanggaran Ham Masa Lalu Melalui Perspektif Penal Dan Non Penal, Makalah Di Sampaikan Dalam Ruang Kuliah, Program Pasca Sarjana, Fakultas Hukum Universitas Islam Indonesia, Yogjakarta : UIM

Ruti G Teitel, (2004), Keadilan Transisi, Sebuah Tinjauan Analitis-Komprehensif, Terjemahan Elsam Dari Transisional Justice, Cetakan Pertama, Jakarta : Elsam.

Satya Arinanto, (2005), Hak Asasi Manusia Dalam Transisi Politik Di Indonesia, Cetakan Kedua, Jakarta : Pusat Studi Hukum Tata Negara

Suparman Marzuki, (2012, )Pengadilan HAM Di Indonesia, Cetakan Pertama, Jakarta : Airlangga.

Teguh Prasetyo dan Abdul Halim Barakatullah, (2007), Ilmu Hukum Dan Filsafat Hukum, Cetakan Kedua, Yogyakarta : Pustaka Pelajar. 
Yohanes De Masinus Arus, The Right To Know The Truth, Kerangka Normatif Mengungkap Kebenaran, Dalam Pencarian Keadilan Di Masa Transisi, Cetakan Pertama, Jakarta: Elsam, 2003.

HAM dan Keadilan Transisional, dalam https://nasional.kompas.com/read/2015/07/30/15272881/HAM.dan.Keadilan.Transisio nal? page $=$ all.

Tosa Hiroyuki, Keadilan Transisional Yang Terabaikan, Tinjauan Ulang Masalah Indonesia Dan Timor-Timur. Pdf, Kobe University, dalam http://www2.kobeu.ac.jp/ tosa/keadilan.pdf 